\title{
Food Safety and the Coronavirus Pandemic
}

\section{Zerrin Toprak Karaman}

Dokuz Eylul University, Faculty of Economic and Administrative Sciences, Buca, Izmir, Turkey

Email: zerrin.toprak@deu.edu.tr

How to cite this paper: Karaman, Z. T. (2020). Food Safety and the Coronavirus Pandemic. Open Journal of Social Sciences, 8, 334-357.

https://doi.org/10.4236/jss.2020.89027

Received: August 27, 2020

Accepted: September 26, 2020

Published: September 29, 2020

Copyright $\odot 2020$ by author(s) and Scientific Research Publishing Inc. This work is licensed under the Creative Commons Attribution International License (CC BY 4.0).

http://creativecommons.org/licenses/by/4.0/

\begin{abstract}
Creating safe places and ensuring the safety of society is an important issue that has always been among the classic tasks of the government. While visible border security has been an important issue in the past, cyber-attacks, biological weapons or new risks caused by the nature that cross borders today and have deadly impacts all of which are difficult to control at the border and threaten security have become prominent at a global level. We have now become a risk society. The subject of this article is to methodically examine the relation between safe food and the Coronavirus which has affected the whole world by threatening the health and quality of life of humans and animals (fauna). Whether plants (flora) are outside the scope of this threat is not yet publicly known. In the case of the COVID pandemic, production activities have almost stopped in many sectors due to human presence being exposed to the effects of the virus because of its "coexisting" habit and many people dying from illness or having their tissues damaged. This shocking unexpected phenomenon, which has moved from the local to national and then international levels, has shown the need to review the things we know in terms of sustainability of life and reframe them. This national and also universal problem of how safe environments and "smart society" relations should be regulated is an issue that needs to be quickly and carefully regulated, in the "New World Order of Corona" where such Corona cases will continue to happen. Briefly, the issue of "health safety" was taken one step further and examined by taking its relationship with other elements into consideration. This study will entail both international regulations and examples in Turkey.
\end{abstract}

\section{Keywords}

Food Safety, The Coronavirus Pandemic, Sustainability, Stakeholder Engagement, Interdisciplinarity 


\section{Introduction: Security and Smart Society Reinterpreting the Concept of Food Safety}

Security is a concept with factual content and rich with terminology that keeps being added as global change and transformation continues.

The creation of a safe environment, in which the security of the users of this place is provided in a network by various public tools, is an important problem of public administration today, as it was in the past. Although there are different environments, the semantic common ground is to "feel safe" in those environments. For example, the elements of the definition of safe tourism include "tourism activities that take place in an environment which is made safe and in which the tourists travel in the area they wish with necessary facilities and tools under the predefined safety measures" (The definition belongs to the author). In short, "safe country, safe mountain tourism, safe city" definitions are introduced by eliminating the conditions that could create "risks", preventing the "birth of a crisis" as much as possible, and updating the risk analysis under all changing circumstances. As in the example of population mobility, biological threats caused by nature, such as the "deadly coronavirus" encountered in late 2019, which had a more widespread impact than armed attacks, drew attention to individuals who travel and from the source country for some reason (business trips, trade, education, tourism). Global population mobility can carry deadly threats around the world, making these threats no more local or regional. Globally caused joint interaction makes the problems common and reveals the need to cooperate and collaborate. In summary, the issue of security is a factual area that changes and transforms according to the changes brought by the day but remains to be a "whole of dangers" in terms of classical doctrine. The coronavirus phenomenon, unlike other natural disasters such as earthquakes, floods, etc. in terms of their effects, has a structural feature that needs solidarity but also makes individual-national reflexes special and prioritized.

In the Turkish National Cyber Security Strategy Guide (2016-2019), there is a link established between the breakdown of critical services and infrastructure, and public order with the concept of security. The elements also include loss of lives, economic damage, and disruption and/or cease of services. Where does the smart society stand within the concept of security?

In recent years, the smart society has been debated with the goal of developing the ability to manage, rather than being afraid of technology. It is a philosophical approach that is associated with the ability to demonstrate the skills of individuals to be prepared for new developments and changes to ensure the sustainable well-being of societies (Society 5.0, 2018). At the center of this issue is the fact that the growing world population faces a new threat every day, such as environmental, technological threats, in both the virtual and the real world. The "super-smart society", which cares about innovation and creativity, which has the capacity to produce useful ideas and resist dangers has become important in order to achieve the goal of global and sustainable prosperity. For success, social 
support is as important as interdisciplinary studies based on participatory understanding and cooperation. The coronavirus pandemic has also led to a factual synergy that preserves and enriches the meaning of the concept of "smart society". It seems that a human-centered society that can adapt to the conditions brought by the day, meet various potential needs, and easily provide products and services to reduce economic and social gaps have taken precedence over the philosophy of machine-centered production. The coronavirus has again strengthened the principle of focusing on individuals and capacity growth in human capital. In addition, due to the characteristic of disaster management, there has been a need to convince individuals by creating reliable information. Instead of activating the classic management style of public administration in disasters where the decision-making mechanisms order people to do something, the administration chose to "inform, make people think, convince them and ensure that people do what is necessary". Due to the "global biological disaster", the issue of fighting against the pandemic has also made national interests a priority" while making legal decisions on public policies.

To summarize being smart is defined as having the ability to "distinguish" between right and wrong, acting with common sense. This definition needs to be updated for it to adapt to new changes every single day. In other words, a smart city is an open-ended concept. In innovative settlements with the appropriate number of residents who have the capacity to create synergy and build organizations, the features of creativity, innovation, and entrepreneurship established with sectoral integrated discipline, are more easily reflected in the formation of cities' personalities. These types of cities are called "smart"1 cities.

The fact that the virus is becoming more deadly and widespread seems to have forced social lives and people in public life to be smarter, "for all". The new threats to human health and food chain are related to the expansion of settlements so that they fall within the borders of virus and bacteria habitat/ecology. Microbes carried by animals became a threat for humans as new fields were chosen for agricultural activities. People expanding their living areas due to the increase of population and the need for food and invading rural areas is not unique to this century. The reasons for measles, tuberculosis, whooping cough and flu are attributed to various animals. Another topic of discussion nowadays is that frozen lands are getting warner and getting increasingly convenient for people to settle on them. However, it is known that frozen soils provide the ideal environment for bacteria to remain alive for a long time, perhaps for millions of years. Viruses are also observed to last for a long time. According to a study, bacteria and viruses of the past are also becoming active on earth as glaciers melt (BBC News, 2017). We better remember that in 2014, researchers revived two important 30-thousand-year-old viruses (Pithovirus sibericum and Mollivirus ${ }^{1}$ Among conceptual relatives of a smart city are digital city, ubiquitous city (U-city), information city, thinking city and ingenious city. The U-city is a city of sophisticated technology built on infrastructures, technologies and services everywhere that aim to increase the value of that city and the life quality by systematizing the administrative functions and processes within the city borders. 
sibericum) in Siberia at a depth of 30 meters (Legendre et al., 2015: p. 8). The conclusion of the research states that due to climate changes triggered by industrial activities, unfortunately, such events will not be uncommon. These events create the right environment for re-encountering with unknown viruses and bacteria.

All these changes require new strategic tactics in terms of space, including personal health. For the society to be safe from various threats, and to provide livelihood and sustainability in the inhabited areas, we aim to effectively use tools, such as benefiting from intercultural differences, transforming threats into advantages through cooperation and collaboration projects, making use of interest groups, using information and pieces of work coming from various groups of young and older adults, of women and men of the informed society, utilizing the knowledge and experience of the past to attain to our goals. In other words, smart society means the ability to reconcile individual and social risk management and manage the crisis in order to ensure sustainable well-being for the future in such a way that the individuals are aware of their duties and responsibilities in all areas. This approach is a process of sustainability. During this process, countries have to "competitively" develop themselves "in the name of social security and freedom" using methods like increasing their social capital, getting stronger in the digital cyber ecosystem, using smart technologies, overtly or discretely tracking their residents' spatial mobility for certain reasons, such as disease outbreaks or multi-faceted crime possibilities.

When any of the main topics known to be related to global and/or regional risks become visible or prominent, directly or indirectly, other threats also appear alongside that issue. Recently, biological, and cyberattacks have come to prominence as much as geological and meteorological threats. At the center of these encountered risks lie the settlements with crowded and congested populations, even though they have different levels of development.

The "global outbreak of virus" with deadly effects has been handled by the Chinese administration as of the end of 2019. It was first expected to be over in a short while just like other outbreaks, but then the concern that it could become permanent prevailed quickly. This event has challenged our daily lives due to the risks it bears. The "fear of death" settled in our lives around mid-April and it now affects public policies on a global scale. We are now experiencing a global reality of fantasia where people say "we would not be surprised if the aliens invaded the Earth". As a result, the term "integrated risk management" has left its place to "integrated triggering risk management". Almost all risks walk arm in arm as if to strengthen each other. This is also called "arm-in-arm risks".

No matter what type of danger it is, we will be discussing its properties and the threats it poses to society. The tools (classic and modern) that were recommended to be protected in a military or non-military virtual (digital) reality environment which used to be prominent in prior classic threats in terms of spatial protection are now changing. In addition, the norms that wanted to protected 
used to be the socio-cultural values of the society. However, the known risks and unknown threats of COVID-19 has made it an obligation for health purposes to refrain from certain cultural behavior patterns such as kissing hands and hugging. The mentioned cultural values are accumulated through centuries, and it is hard to ignore and stop practicing them.

The word "pandemic" used for COVID-19 comes from old Latin and is de-

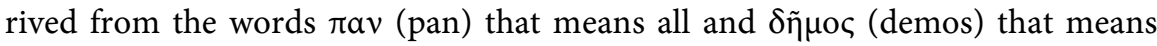
people. We experienced the pandemic on a global scale by remaining in our homes and staying "isolated" from others. If such an event had never happened, this would have remained as a story from a fantastic reality novel. However, this pandemic is not a social reality that we have to study from multiple perspectives. Now, the times we enjoy the most, the rituals we socially practice such as hugging each other, kissing on the cheek, shaking hands, the social and cultural activities, and even touching and feeling a fabric or a fruit are over. The habit of greeting each other by "kissing the young on their eyes and the old on their hands" seems to be put into cold storage. But their shelf life may never be over. Cultural habits do not constitute the essence of this article, but they are of utmost importance in the fight against the virus. In terms of narrative integrity, it is inevitable to not mention the subject from time to time.

The elements of safety as defined by the United Nations (1994) mostly encompass events that disrupt the safe environment and proper functioning of daily lives occurring due to economic, natural, or political reasons that happen slowly or suddenly. These events have the property to affect or trigger each other in terms of causing danger. The specified subjects signal economic, socio-cultural and similar risks. In today's circumstances, some descriptions have a strengthening effect on the definition of safety given above. The reduction or disruption of food resilience due to various disasters has added the element of "government's responsibility to provide food and drinks in order to protect and safeguard its citizens" (FAO, 2020) to the definition of safety. As a matter of fact, people all around the world have started to stock food, and the administrations of developed countries are guaranteeing that they have "sufficient levels of food stock". Turkey is also among the countries which were successful in providing the food stock to their citizens.

In terms of global safety, natural or many other civilian activities created global dynamics that require the government's collaboration. However, in such an unpredictable situation, for how much longer will the governments be willing to provide "food support" as they were while providing "protective masks" in terms of commodity support? Or will we continue to import agricultural goods while our producers are looking for support? Nevertheless, the legal decision-makers in Turkey have supported agricultural activities and excluded the workforce from "the scope of quarantine". And this move was a rational method.

The improved definition of safety has various areas within. These areas are 
listed below (UN, 2009: p. 6):

1) Economic: Creation of employment opportunities and measures against poverty.

2) Food: Measures against hunger and famine.

3) Health: Measures against disease, unsafe foods, malnutrition, and lack of access to basic healthcare services.

4) Environmental: Measures against environmental degradation, depletion of resources, natural disasters and pollution.

5) Personal: Measures against physical violence, crime, terrorism, domestic violence, and child labor.

6) Community: Measures against ethnic, religious and other identity tensions.

7) Political: Measures to be taken against political repression and human rights violations.

However, terror pressure can be added to each of these issues. These issues all together are embedded in the fundamental philosophy of the Universal Declaration of Human Rights ratified by the United Nations General Assembly on 10 December 1948. Representatives of 48 UN member states voted "yes". Turkey is among the countries that accepted the Declaration. The statements of "Everyone has the right to life, liberty and security of person" (Article 3) and "All are equal before the law and are entitled without any discrimination to equal protection of the law. All are entitled to equal protection against any discrimination in violation of this Declaration and against any incitement to such discrimination" (Article 7) are directly related to the subject. According to the World Health Organization's definition, threatening and dangerous environments are suitable environments for all types of terrorism.

In this study, the issue of "health safety" was taken one step further and examined by taking its relationship with other elements into consideration. While emphasizing the food dimension of national security, efforts to strengthen the strategic infrastructure and superstructure equipment of settlements are also important. The fundamental elements of human safety are 1) multi-industrial, 2) comprehensive 3) having original conditions 4) preventive. The relationship between the food-society resilience of a healthy individual will be analyzed with an integrity-enhanced model. The future looks likely to develop through health and water intelligence, and the protection of health conditions. In summary, the wide variety of subjects being studied makes interdisciplinary and transdisciplinary studies necessary. The current developments, obeying the rules put in light of knowledge, the chaos that is caused when the rules are not followed are all signals that it is time for knowledgeable and smart societies.

\section{The Safety of Smart Cities or Healthy Cities}

The narrative of "smart cities", which composes the main theme of International Habitat meetings is comprised of checking the profile of the population, considering the land and city planning in terms of development and urban economy, 
evaluating housing and basic services in the light of governance, human rights, the rule of law and ethical/universal values. It is important to maintain each subject area at the quality of life standards and to increase the degree to tolerate unexpected changes within their own dynamics.

In contemporary societies, interdisciplinary studies with a broad perspective within each subject seek appropriate answers, focusing on increasing theoretical attention. "Social resilience" in terms of health affects many fundamental issues, starting with one's health. What should be considered here is that society also has a responsibility to protect the health of individuals and has the power to influence legal decision-makers and administrators. In general, however, this issue is narrowly associated with the person, the environment and the health service.

The following are some selected examples in terms of themes and disciplines, based on the stated need for interdisciplinary cooperation. If cities receive large numbers (thousands) of migration, this means that it will affect the issue of being a safe city (such as social, economic, cultural factors as well as sectoral housing and housing-related services and health). The "asylum seekers" who preoccupy Turkey could be under a health threat in the areas they are currently living and this is something we need to question in times of COVID-19 pandemic.

With regard to domestic population's mobility, one part of the population returns to their previous "settlements" from which they migrated, which they consider to be safer, while people who have property on the coasts tend to move to the less populated coastal districts. And this is considered another type of population mobility. Although this profile does not impose an economic burden on the town in terms of population characteristics, it damages the notion of safe city because it creates unpreparedness at coastal municipalities due to health services that could be insufficient. In fact, the issue should not be seen as only limited with the "health and hospital" concerns when the fact that the towns are mostly overpopulated by people who come outside of that town's borders during holiday seasons and meet their food and other needs there. This has caused the limitations of passing from one city to another. Some of these cities have metropolitan municipalities. This measure is in accordance with the exceptions stated in Article 23 of the 1982 Constitution but this legal ground was not mentioned while announcing the preventive measures. By the way, the regulation of the Council of Europe of which we are a member on COVID-19 outbreak and the freedoms during the pandemic are given below.

The COVID-19 outbreak has been managed in line with Article 15 of the Council of Europe's Convention for the Protection of Human Rights and Fundamental Freedoms. Article 15 of the Convention is on "Derogation in time of emergency". The first subparagraph of the Article states that In times of war or other public emergency threatening the life of the nation any High Contracting Party may take measures derogating from its obligations under this Convention to the extent strictly required by the exigencies of the situation, provided that such measures are not inconsistent with its other obligations under international law. However, once these measures are repealed, the provisions of the conven- 
tion will come into full force again (Council of Europe, 2020a).

For a healthy and food-resilient city, the issues below can be analyzed. A collaborative and interdisciplinary work needs to be developed in terms of owning an idealized subject and rational use of resources. In fact, interdisciplinary thinking is not a new phenomenon. As we walk through the dusty shelves of history, we see that Hippocrates (460-370 B.C) in the 4th century B.C is the earliest researcher to form such a union by bringing together the histories of Medicine, geography, and anthropology in his health geography review named "On Airs Waters, Places" (Hulme, 2016: p. 38). As you can see, some issues do not remain on the dusty shelves of history.

While analyzing the indicators of life quality in settlements, we see that the terms of natural, scientific, and social sciences and their set meanings develop by borrowing from other disciplines and start to have common grounds. We also observe that they need political and religion-based discourse and practices to be used as tools. The subject and its interdisciplinary relationships were laid out to give the reader an insight. The interdisciplinary union is explained with the help of Figure 1. As you can see from the figure that depicts the importance of interdisciplinary studies, holistic questioning and analysis can only be established through the partnership of natural, technical and social units. The omission of one or more of these elements prevents a good investigation that leads to conclusions.

However, as in the case of health, social, and technical issues, in general, there are agrouppments and it is not possible for one study to benefit from the results of another. The best example of this is composed of the studies under the name

"Healthy Cities". The subject mentioned below is related to this.

As you can see in Figure 1, the perception of safe cities or ensuring the security

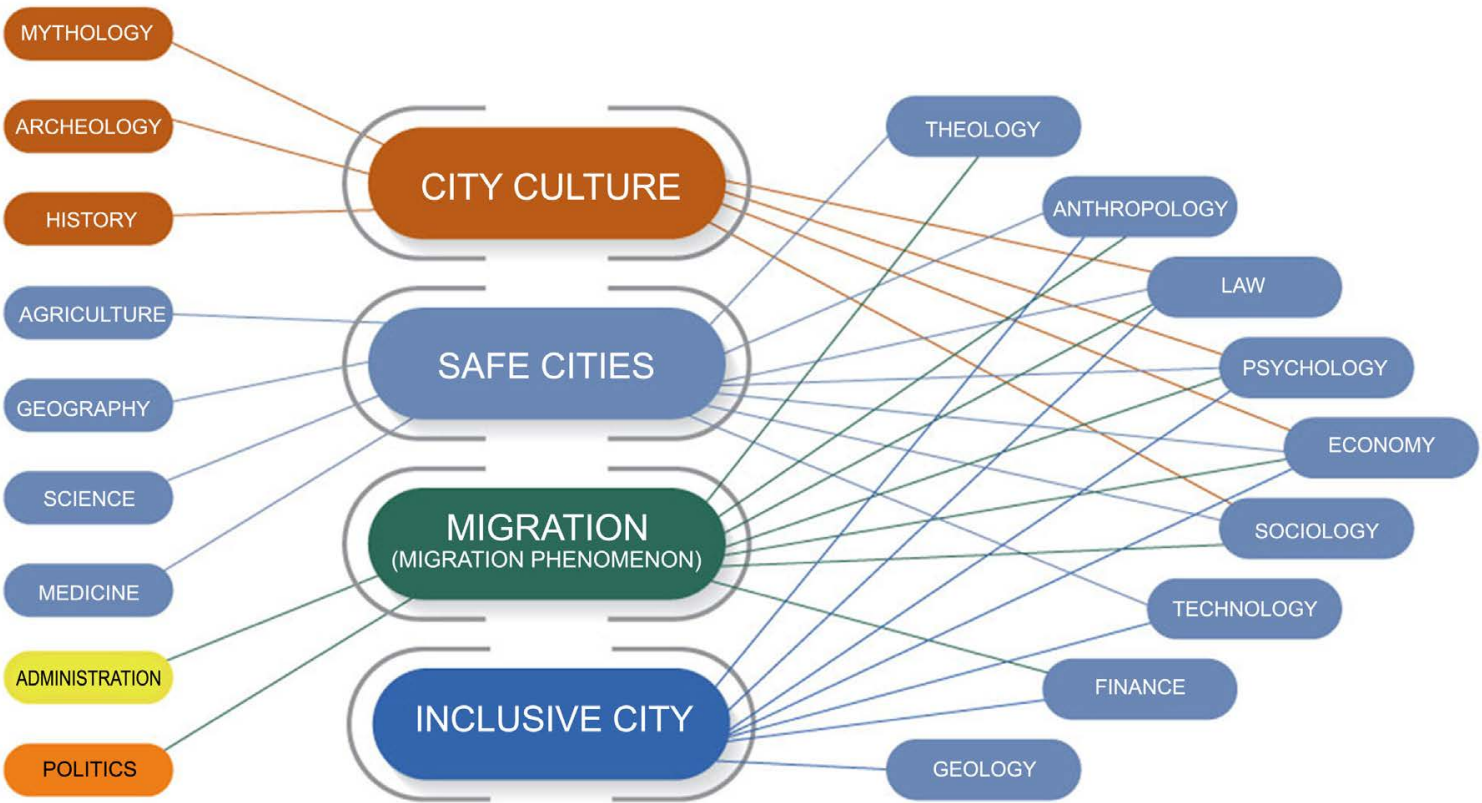

Figure 1. The associative network analyzing the concepts of urban culture, safe and inclusive cities from an interdisciplinary perspective. 
of cities cannot be explained by police measures alone. Today's cities do not develop with an increase in the city's population. Especially settlements with high economic externalities are shaken up not only by internal migration, but also by waves of legal and illegal external migration. This situation causes cultural reciprocity and basic public services (health, education, culture, infrastructure, transport) to be left under the pressure of population. Therefore, it is important that the decision and executive bodies ensure the participation of local people when creating local policies in the cities. In this participation, it is necessary to carry out managerial works with the support of interdisciplinary studies; and the geographical risks of places must also be taken into account.

Creating healthy cities while working on the sustainability relies on basing the strategic plans on the city's history, sociological and intellectual accumulation, its ability to use technology and to be open to new ideas and the informational support. In short, what is needed is managerial wisdom. Due to the difficulty of interdisciplinary work in practice, this expectation cannot be realized. Below, this topic is summarized for Turkey.

In 1977, the World Health Assembly called for "Health for All" by putting a very important social goal before governments, and 1981 was the birth year of the theme of "health". By the year 2000, the World Health Organization (WHO) initiated the preparation of action plans for global strategic works, aiming to ensure that everyone in the world has access to the level of health necessary to lead socially and economically productive lives. An important point on the philosophical basis of the studies that constitute the basis for this call for mobilization is that the expression "Health for All" does not mean the end of diseases and impossibilities or that doctors and nurses will take care of everyone's health, but rather that it means "everyone has access to the resources and basic health care that is required to be healthy".

Turkey also has followed up on these developments. The Healthy Cities Association was founded in 2005, and now in 2020, it has 74 member municipalities. Their work is based on the theme of "sustainable development and sustainable cities" (Turkish Healthy Cities Association, Date Not Specified). The Union aims to bring together healthy cities and candidate cities to create health-based planning, sustainable development, governance, and social support. The Union also desires to reduce the inequalities in and between these cities, to create and sustain healthy cities. Although the word "interdisciplinary" is not used in the statement, we can say with an extended interpretation that it maintains its expected functionality by supporting studies of many disciplines.

Although during the founding years, member coordinators were mostly selected among "physicians" due to the first impulse, as of the end of 2019, the interdisciplinary awareness has risen with the participation of other professional groups, such as "physicians city planners, environmental engineers, sociologists, landscape architects, veterinarians, journalists, nurses, map technicians, civil servants, occupational safety specialists, graduates of economics and business, dentists, translators, public relations experts, interior designers, and chemists". 
When the Director of the Union's statements are questioned by asking the following question: To what extent do you work on subject criteria and professional partnerships when it comes to projects and publications in your interdisciplinary or transdisciplinary studies? (information collected on 08.11.2019) He told that some examples of the subject matters are the fight against addiction, global warming, stray animals, physical activity, greenhouse gas emissions, waste management, the use of bikes in urban areas, light pollution, and accessibility for disabled people. Various awareness studies, national and international congresses, conferences, workshops, and training sessions with expert academics are organized on these subject matters in interaction with institutions.

If an assessment on a national level were to be made, based on our observations, in general, public, private, and civil partnership is achieved in these studies around one issue, but only the discipline leading the meetings and, at best, the neighboring disciplines are included. As mentioned above, the social sciences and the natural sciences rarely come together. The development and replicating effect of new ideas as a whole remains weak, as often re-evaluations are not written down once they are done.

\section{Protection of the Land and Food Administration in Turkey within the Structure of Administrational Safety}

The word safe is used for describing situations where the state and circumstances of being safe are provided for a person or an environment. Whereas security means the system that keeps people away from danger and makes sure the threatening situations are blocked. These concepts together mean the actions and methods that aim to prevent losses of all kinds and to provide a safe area for the society.

In accordance with the provisions of the Turkish Presidential Order No. 1 on the Organization of the Presidential Office, the following issues related to security are directly related to the president, who has executive authority by being the head of the state. The government official with the highest rank, the Head of Administrative Affairs is the highest in the chain of command in the Directorate of Administrative Affairs of the Presidential Office (PO1, Article 5). Among their duties is "to do the necessary work to ensure coordination on internal security, external security, and fight against terrorism" (PO1, Article 6/ç). The duties of The General Directorate of Security Affairs established for this purpose (GO1, Article 9, 2018) are listed below:

(a) to ensure coordination with public institutions and organizations related to the security policies and strategies of the state, to monitor, evaluate and report the implementation of the determined policies.

(b) to compile, evaluate, and coordinate information on the issues that required the declaration of a state of emergency in these regions.

The council of policies is asked for their opinion on the subject matters defined in sub-paragraphs (a) and (b). 
Operations related to terrorism and protection measures are defined as informing the public.

In the new public administration organization determined by presidential orders, the "Presidential Council of Policies" supporting central-level security structures established by Presidential Order No. 1 (PO1, Article 20) is an effective model of administrative tools as long as it considers social capital.

In Turkey, the relationship between ownership and efficient operation of land and the relationship between farmers is explained in detail in the Constitution. "The state shall take the necessary measures to protect and improve the efficient operation of the land, to prevent its loss by erosion, and to provide land to the peasant engaged in farming who has little or no land. For this purpose, the law can determine the width of the land according to different agricultural regions and types. The provision of land to the farmer who has little or no land cannot result in the reduction of production, the shrinking of forests, and the decline of other land and underground fortunes. Lands distributed for this purpose cannot be divided, transferred to others except in the provisions of inheritance, and can only be operated by the farmers to which the land was distributed and their heirs. In case these conditions cease to exist, the principles concerning the reclaiming of distributed land by the state shall be regulated by law" (1982 Constitution, Article 44). Within the framework of this provision, the government policy is based on the balance of protection and use of land that never allows the loss of agricultural land.

Besides, an important subject matter has been analyzed under the title "Agriculture, Animal Husbandry and Protection of Workers in these Branches of Production". According to this provision, "The state makes providing the business tools and equipment and other inputs easier for those who work in agriculture and animal husbandry in order to prevent the misuse of and damage to the agricultural land, pastures, and meadows, to increase the plant and animal production in accordance with the principles of agricultural production planning. The state shall take the necessary measures to make the best of plant and animal products and to ensure that their true values are given delivered to manufacturers" (1982 Constitution, Article 45). However, the withdrawal of agricultural lands due to administrative regulations or due to the expansion and population pressure of the cities within its nature, as well as the lack of administrative support from agricultural production, may inhibit its efficient use (Toprak, 2019a). Furthermore, the increasing differentiation and severity of disasters is causing the agricultural sector to decline.

The fact that Turkey is a peninsula due to its geographical features and the length of its coasts ( $8333 \mathrm{~km}$ of coastline including islands) has made the issue of coasts a separate subject matter. In the article about benefiting from the shores under the title of Public Interest, "The shores are bound by provisions and administration of the State... The depth of the coasts and coastlines based on their purpose of use, and the opportunities and conditions for people to benefit from 
these places shall be regulated by law" (Constitution, Article 43). It is important to revise the Coastal Law in order to eliminate the negative effects of events, especially of the nature on the shores and to include the coasts in the scope of integrated planning. The fact that no hospitals can be built on the shores is another important aspect (Toprak, 2019b).

In terms of local authorities, the provisions relating to the use of agricultural land are integrated into the Metropolitan Municipality Law (No. 5216) and the Municipal Law (No. 5393). The tasks of the Metropolitan Municipality include "ensuring the protection of the environment, agricultural areas, and watersheds in compliance with the principle of sustainable development, afforestation, gathering unhealthy workplaces, entertainment areas, other workplaces that have an impact on public health and environment into specific and separate sections of the city, defining the areas for stocking and selling construction materials and junkyards, for stocking rubbles, sand, and pebbles, for stocking and selling wood and coal, taking necessary measures to prevent these from damaging the environment, planning or making other parties plan the metropolitan waste management, recycling, storing and providing the necessary services for destroying solid waste and excavations except for gathering solid waste at their sources and carrying them to the transfer stations, planting and managing or making other parties plant and manage facilities for these purposes, providing services of industrial and medical waste, planting and managing or making other parties plant and manage facilities for these purposes, collecting, or making other parties collect the waste of sea vehicles, refining these and making the necessary arrangements thereof (Law No. 5216 Article 7/i).

And the Law No. 6360 which made the borders of the city and of the metropolitan municipality the same states that (Added paragraph: 2/11/2012-No. 6360/Article 7)" Metropolitan and district municipalities can perform all kinds of activities and services with the purpose of supporting agriculture and animal husbandry". In this way, the definition of "city", which is now based on the function of "non-agricultural production" (all municipalities regardless of size), has now changed. Administratively, villages were converted to neighborhoods, and in 30 metropolitan municipalities with no village administration, rural area activities were also guaranteed. This is actually the association of the concept of "rural and urban" integrity, which has long been considered academically, with city-level legal regulation. In theory, organizing rural and urban integrity with spatial strategy plans makes the city smart. And taking advantage of rural areas' food power to increase social resilience as an important goal is included in the legislative regulations. In practice, it is essential to act according to the procedure which is based on this philosophy.

When examined in terms of Municipal Law No. 5393, it is aimed to keep the municipality, acting in relation to land and housing, "away" from "agricultural land", which must be protected by special laws. As a matter of fact, "To provide regular urbanization, to meet the housing, industry and commerce needs of the city, the municipality has the authority to create pieces of land that has the infra- 
structure and is available for construction, to build, sell, rent housing and collective housing, and to buy and expropriate land for these purposes, trade-in these lands, to collaborate with public institutions and entities and banks, and do collective projects with them within the boundaries of the municipality and neighboring areas" (Law No. 5393, Article 69).

Although these regulations are from a legal approach in which the importance of agriculture is at the forefront, rural area activities within 30 metropolitans and 51 other cities have considerably declined. According to TurkStat's data, the administrative rural population rate in Turkey is around only $1.47 \%$ in 2018 . Of the $82,003,882$ inhabitants this year, the ratio of those living in city and district centers is $92.5 \%$ while the ratio of those living in villages and small municipalities is $7.5 \%$. Another point of the issue is that the share of agriculture in GNP continued to decline to $7.9 \%$ as of the end of 2012 and became $7.4 \%$ at the beginning of 2016. In the meantime, the agricultural results between 2005 and 2015 in Turkey have shown that farmers gave up planting 27 million decares of agricultural land, 600 thousand farmers withdrew from production, and wheat planting areas have been reduced by 14 million hectares. Between 2012 and 2015, potato planting areas have decreased by 600 thousand acres (Haber, 2015). As of 2019, the number of farmers in Turkey has decreased by $38 \%$ in the last 10 years, while agricultural areas have shrunk by $12 \%$ in the last 15 years and vegetable gardens have narrowed down by $15 \%$ (Euronews, 2019). In addition to the decline in agriculture and the continuous rise of population, the food, education and accommodation needs of the additional population of 12.8 million, which is composed of immigrants or their offspring with high birth rates in Turkey has been mentioned in the World Disaster Report of 2018 (International Federation of Red Cross and Red Crescent Societies, 2018: p. 9)2.

The fact that 3/4 of Turkey is composed of mountainous areas should actually be seen as a strong suit and an opportunity. Although enclosed in the definition of the city, these areas' elevations and their inaccessibility preserved the rural areas and forest presence. As mentioned earlier, since the provisions of Municipal Law No. 5393 allow, agricultural activities can be carried out if local people and related municipalities are interested. In this case, although the areas where agricultural activities continue change from city to city, it can be predicted that we have more than $8 \%$ rural presence in the whole country. Methodically, when the "City and Metropolitan Unity" is evaluated within the rural and urban ratios of 2012 before the implementation of administrative boundaries, even the most pessimistic estimate is that there is $25 \%$ rural use in Turkey. Society hopes that it will grow further.

While agriculture is the most important measure of resilience that keeps a country alive, the fact of rapid agricultural loss in Turkey has become even more ${ }^{2}$ According to the World Disasters Report (2018) of the International Federation of Red Cross and Red Crescent Societies, the population movements caused by external migration of over 12 million asylum seekers coming from Syria since 2012, especially into Turkey is found to be significant (International Federation of Red Cross and Red Crescent Societies, 2018: p. 172, 185, see. figures. $7.4,7.18)$ 
noticeable due to COVID-19. Previously, the people who were interested in "price" instead of quantity used to associate this price increase only with the "middleman", but now the question of why the fields do not grow green anymore has started to be examined in all its aspects through the media and academia. In fact, from the beginning of urbanization movements as a whole (the 1960s), unsanitary settlements were formed due to the political will that could not resist economic and social pressures. It would be appropriate to look for the replicating effect of the lack of scientific data in this apparent physical deterioration. Habitat areas such as soil, forest, open areas, beaches and valuable wetlands have become vulnerable to extinction and multifaceted pollution impacts that are preventable.

The fact that the agricultural sector needs to be developed has become an issue and entered the agenda of public opinion after the coronavirus pandemic. The issue of agricultural activities being supported by the administration can be considered as an opportunity created by the phenomenon of coronavirus. In addition, periodic seasonal population movements also affect the agricultural industry. The best example of this observed in Turkey is that the population which is considered to be temporarily staying in the coastal settlements composed of people who come for seasonal domestic tourism for three months on average did not return to their permanent residencies due to the pandemic. Distance education and the increased opportunity of remote working also triggered the longer stays in the second housing, and seasonal grocery stores decided to extend their closing time. There has been a need to direct services that are normally for local residents only to secondary housing residents as well for more months. The expectation that the pandemic will continue is also a signal that new service tactics including food strategies will need to be developed by local governments due to the growing population with internal migration that has become permanent in the new local are.

When considered as a whole, population mobility towards rural areas with the foresight to better protect their health will also change municipal services and food demand outside the prescribed timetable. This issue brings us to "selfishness", which can be explained by" culture". Although secondary housing owners have economic independence and education, in this case, swarming into areas where they normally go only for a limited period at certain times with a self-protection reflex, actually creates a security threat. Therefore, the administration is, rightfully taking precautions to stop traveling. These issues written above have not been examined by the literature within the "global epidemic" environment since they have not been encountered before. However, there are analyses of overpopulation effects caused by people swarming into a particular area for different reasons, such as enjoying the sun, the sea and the beaches (Toprak, 1990). The information obtained in these studies is adaptable to this new situation.

One of the effects of the COVID-19 pandemic in the short term is the subject of agricultural resilience, which, as emphasized in the text, means human resi- 
lience. In an environment where commercial choices made during distribution of goods and services within the network of diplomatic-commercial relations created by globalization of contiguity turn into ecological pressure and imperialism over time, countries found themselves under the obligation of providing food for their residents "due to food safety" and closing their border gates. This created a transformation in the discussions around the return to national sovereignty in terms of food administration. Prior to COVID-19 exporting the excess production besides the routine practices of 1) producing the "food" that is not consumed by their own residents and offering it to foreigner customers or 2) not considering the local producers' interest while importing food that is already produced within the country have been "realized" during the discussions on commercial threats which peaked especially in the last two years between China and USA on both national and international levels.

For which countries is this realization going to develop sustainability? As a consequence, these issues which are considered worthy of questioning will be better understood in the coming years when administrative confidentiality is nonexistent and access to information is allowed. In fact, this issue has been occupying the world agenda for a long while and the basis for cooperation has been sought in various meetings. Below, this topic is analyzed by taking national and international levels into account.

\section{National and International Interaction in Food Safety Administration}

International organizations continue their environment-based activities in line with the conditions of the day, and in accordance with their missions. It is possible to make sense of the principles without disrupting the basic philosophy within the circumstances of the day. Below are the evaluations thereof.

According to the Article 17 of the Rio Declaration on Environment and Development (United Nations General Assembly, 1992), "Environmental impact assessment, as a national instrument, shall be undertaken for proposed activities that are likely to have a significant adverse impact on the environment and are subject to a decision of a competent national authority," and the Article 19 states that "States shall provide prior and timely notification and relevant information to potentially affected States on activities that may have a significant adverse trans-border environmental effect and shall consult with those States at an early stage and in good faith".

European Urban Charter (Council of Europe, 1992) is one of the treaties of the Council of Europe on Local and Regional Administrations Congress (Toprak, 2014). Issues under the Charter's Health section have been reinterpreted by making associations with COVID-193.

"Cities have special potential in improving and providing health conditions. The social and physical environment in which people are present and their life${ }^{3}$ For the original version of the European Urban Charter (1992) see (Council of Europe, 1992). In the evaluation of the issue of health, the full citations are given "in quotes and in italics". 
styles are the main determinants of health". In addition, the Charter mentions the role of local governments as effective administrative units in urban space in establishing public health policies. This determination cannot be neglected for the subject of epidemics. Issues such as identifying and reducing disparities in health conditions, meeting specific health needs and requests of disabled groups, and creating healthier solutions through cross-sector work are valid considerations as per our topic. Another notable case is the strategic importance of "agreements that establish political binding and willpower in taking interest groups on health into account." The situation described in the Charter as "above all, it is especially important to establish social conditions that will enable people to be able to support themselves and each other and to take care of them in cases of sickness or accident" is the exact possible scenario example for when hospitals, depending on their sizes, could be "left insufficient".

In addition, protecting environmental health by creating comprehensive urban environmental policies, providing an equally distributing the basic needs of people for good health conditions in a reliable and healthy way and allowing them to improve and sustain their lives, and finally taking the unnecessary stress and pressure off of the consumers are among the basic principles. Also, it is advised to create rigid policies in terms of providing safe and healthy drinking water; organizing the demand and distribution of daily consumer goods; regulating floor cleaning of food factories and food consumption areas with strict legal provisions by increasing the food quality control procedures, and providing and distributing basic public and infrastructural services.

A healthy society is described in the European Urban Charter (1992) as " $A$ society which enables people to look after themselves, individually and collectively and provide general care in the event of sickness or accident'. The elements of a healthy society are depicted as a group of people which is 1) individually and 2) collectively able to take care of themselves. Based on this definition, some examples of health society actions could be listed as providing support for the work of volunteer groups and organizations interested in public health by creating health centers that expand through neighborhoods; making it possible for the residents of the city to work with health facilities (like health centers, hospitals, and outpatient clinic management-related commissions), decision-makers, and advisor institutions, providing necessary training on being preventive physicians for experts and volunteers, and finally promoting participation through local authorities and supporting such activities.

European Urban Charter (1992) emphasizes the partnership between locality and international programs, as urban health is of international importance. The Charter recommends that "each city should be able to exchange experience and knowledge of new public health studies within a network to be expanded; develop common behavior, and legalize health-related and private political initiatives'. When the degree of threat increases, we observe that societies prefer to use their own means and tools primarily for their residents, and when these resources are not enough, they call for "humanitarian aid". This phenomenon is 
also not very surprising.

When the World Health Organization's (WHO) strategies "based on a health strategy for all" were analyzed in terms of COVID-19, it was understood that WHO places emphasis on individual protection and prefers interstate and public information. The web page also contains country-based technical guides, status information, and technical developments. It is seen from the review of the website (WHO, 2020) that it does not execute a strategy through local authorities as regulated in the Urban Charter. This suggests a new perspective stating that individual behaviors need to be managed instead of managing groups of people due to the fact that the disease is global and therefore, has to be managed on a central-level. The World Health Organization has made contact with the voluntary organizations that serve as bridges between the administration and the public and asked for their support. This means that WHO utilized the relevant voluntary organizations' capacity to better interpret the course of events due to their voluntary activities.

Undoubtedly some of the basic elements of democracy such as "solidarity, active participation, and partnership in the solution" coincide with ensuring the principles of sustainable health. As laid out in the European Urban Charter, "Without the principle of local democracy, human rights in towns are precarious. The satisfaction of physical, social, and emotional needs can only be established and respected through an open dialogue between official management and individual members of the urban community." This approach is understood to be generally valid.

As far as health is concerned, it is also important to ensure that those affected by the rules and decisions are given the right to publicize and give an opinion on the issue and to actively participate in the decision-making processes. We can assume that making people of all ages who fought against COVID-19 and defeated the disease tell their experience and opinions, in other words, "sharing" their story has a positive impact on the public opinion. In terms of the evaluation of the event and the spread of its effect, the significance of evaluating the people who experienced it together with expert opinions is obvious. We need to see that the smart society approach creates structures that find social support easier. The Urban Charter focused more on giving permission to active participation in the democracy for the public in local authorities. But it would also be useful to evaluate and solve the problems by creating and including democratic structures in the central administration, mechanisms that take the public and their experience into account.

The personality of settlements is emphasized in the Urban Charter in terms of managing the health principles for sustainable living. The Charter underlines that "the settlement's regional affiliation, its location, its population, its spatial extent, its hinterland, its weather, its form, its color, its origins, its history, its function-all of these are elements which mark it off from other towns".

The instance of COVID-19 falls within the boundaries of the following provi- 
sion: "Deciding priorities and making proposals are not a matter for a single professional, any one single unit or for chance. Such decisions must be based upon an initial and regularly up-dated analysis, covering the city's special features, potential, activities, development capacities and resources". For innovative and creative settlements, it is important to ensure participation, especially for young people, and to restructure issues such as "work, housing, environment, culture, recreation, education, education and health" under the new conditions of the day.

The Council of Europe has adapted its work program for local governments to COVID-19, particularly in accordance with the above-mentioned principles (Council of Europe, 2020b). Here are some of its adaptations: Current co-operation efforts include the launch of a new project with special emphasis on Mostar in Bosnia and Herzegovina and the finalization and monitoring of proposals for new projects to be implemented in Georgia, the Republic of Moldova, and Kosovo. In addition, there are project activities in Armenia, Ukraine, Morocco, and Tunisia. 13 Ukrainian municipalities plan to implement local initiatives for more ethical, innovative, and inclusive policies and practices and to organize workshops for their representatives. Studies in the field of Foreign Relations include planning a workshop on Sustainable Development Goals (SDG) with the European Committee of the Regions, planning a meeting of the Congress/Committee of the Senior Group of Regions, and contributing to the preparation of the World Forum. It is seen that the Chamber of Regions (a body of the Congress of Local and Regional Authorities of Europe) has started revising the proposals of its future activities with an analysis of the lessons taken out of the current crisis and the problems encountered. Upon the effects of the pandemic on groups, especially regional authorities are leading the way to ensure the necessary coordination by coordinating the municipal activities within their regions and their responsibilities in the area of health. Another purpose of the planned works to be carried out with national authorities and generally neighboring areas beyond the national borders and the due-diligence is to contribute the formation of a common European policy for tackling similar trans-national crises in the future.

In line with this issue, Ankara Metropolitan Municipality was the first (2020) to establish a website that allows sharing information about COVID-19 among member state capitals ${ }^{4}$.

While the general public remained in their home due to COVID-19 and the related slogans telling "stay home, stay alive", agricultural activities needed to be sustained for offering additional support to social resilience. Institutions provide information on different aspects of the subject. Information regarding this issue ${ }^{4}$ The pioneer Ankara Metropolitan Municipality, launched a website connected to the platform "The Capitals' Alliance against COVID-19". The website allows the cities to share their measures during the fight against COVID-19 (Capital's Initiative for COVID-19, 2020). The capital cities below joined the platform before the access date: Athens, Baghdad, Bangkok, Banjul, Bishkek, Brussels, Budapest, Buenos Aires, Bucharest, Dnipro, Doha, Guanco, Islamabad, Canberra, Kharkiv, Kyiv, Nicosia Turkish Municipality, London, Ljubljana, Maputo, Moscow, Nur-Sultan, Paris, Beijing, Pristina, Riga, Sarajevo, Sejong, Seoul, Shenzhen, Singapore, Tehran, Taipei, Tallinn, Tbilisi, Tirana, Tokyo, Tunisia, Ulaanbaatar, Washington, Vienna, Zagreb. 
is provided on the web pages of the Ministry of Agriculture and Forestry and the Provincial Directorates (Izmir Directorate of Provincial Agriculture and Forestry, 2020).

Besides, the communication works in cities will be carried out with the leadership of the governor and under the responsibility of the provincial health director. The stakeholders will be Provincial National Education Directorate, $\mathrm{Mu}$ nicipality, Local Media, shuttle drivers, taxi and other tradesman chambers, universities, provincial offices of mufti, and the garrison command. The cooperation strategy with institutions which are deemed to be useful and with "civil society organizations" is planned. The documents prepared for information are shared digitally on the website https://hsgm.saglik.gov.tr/tr/COVID19. Public Health General Directorate (2020) has publicly announced that provincial health directorates will publish their activities on their web pages, redirect the visitors to the campaign web page and share posts via corporate social media accounts. An address for feedback is also provided. These information sessions include information about occupational health and safety for the general public and interest groups.

The issue of health is primarily associated with nutrition opportunities and access to food. The society can be categorized as "groups with no food safety", "groups susceptible to unsafe food" and "groups with food safety". The complementary element of this categorization is related to structure, stock and food durability. The lack of security affects all three groups, depending on the given endurance indicators.

The unsafe food environment can transform resilience. This varies depending on the nature and duration of the shock. When stocks become critical, it is envisaged that food insecurity will occur and that over time all income groups will be affected in this non-resilient environment, starting from poor groups. Figure 2 below shows the food resilience and management in detail.

When the subject of health is evaluated with; deadly infectious diseases, unsafe food, malnutrition, and constraints of access to basic health services, it becomes a primary area of interest for disciplines such as health, economics, sociology, psychology, geography, law, administration, and natural sciences/technology (agriculture, environment, etc.). Interdisciplinary evaluations go hand in hand due to contemporary developments and knowledge accumulation. The known accumulation of information and accountability also affects this evaluation. In this respect, the information obtained should be evaluated together with related research and technologies, public opinion research, information banks, and public participation meetings with experts of multiple areas.

First, it is important to develop an idea, to imagine and to understand applicability. In the creation of this logical framework, the concepts of "users", "user needs" and "user interaction" are noteworthy. In scientific studies, researchers are responsible to everyone. In other words, it is necessary to act not only respectful of public accountability but of the involvement of stakeholders, and consumerbased or sectoral sensitivity. There is greater responsibility on interdisciplinary 


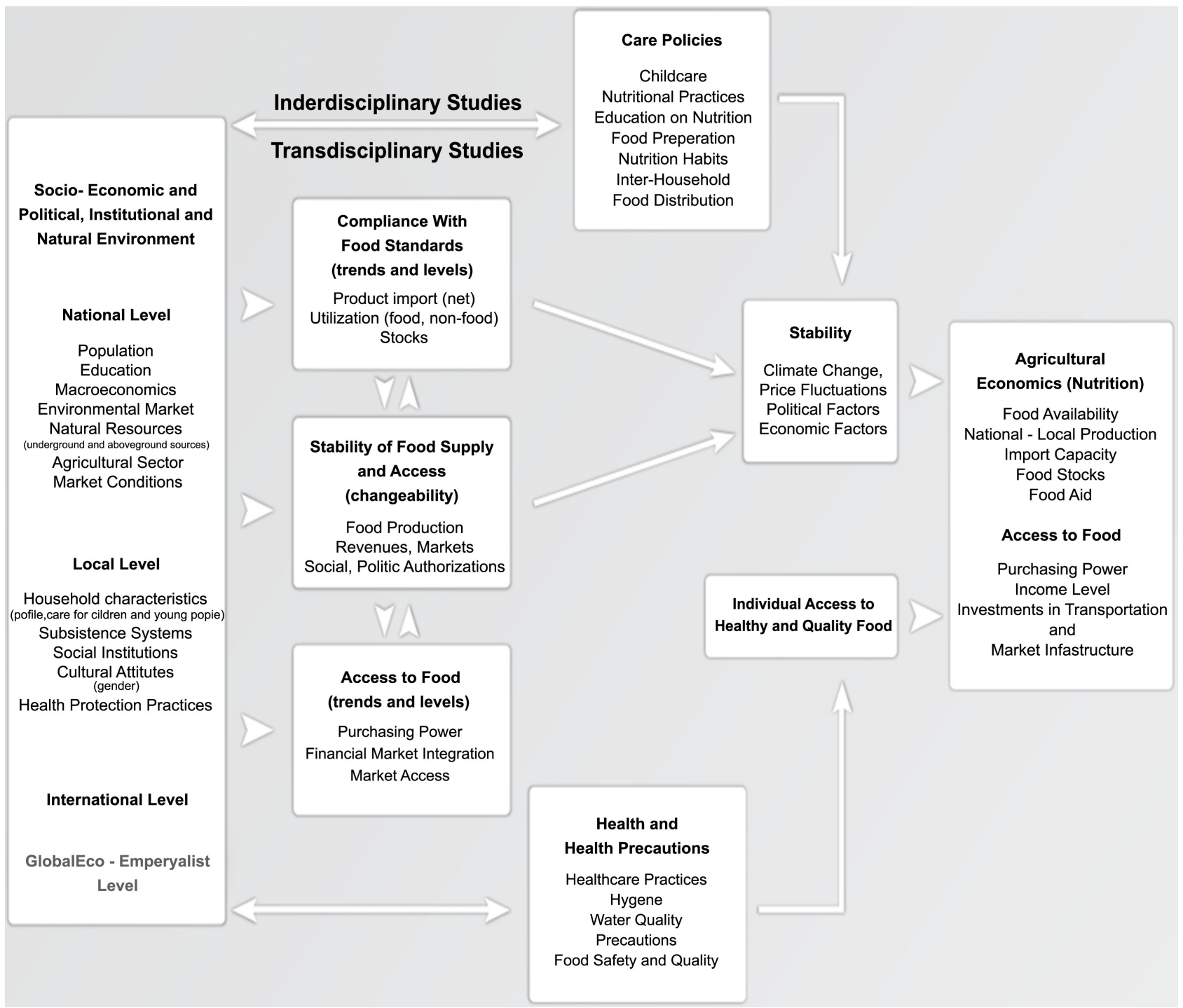

Figure 2. Compare, Hendriks and Maunder, 2006: p. 26, fig. 2.

studies and the tendency to verify through various channels is very present. Scientific studies that require to be exhaustive are becoming increasingly expensive. Scientific activities can be carried out with "belief" and "financial support". This development is based on the philosophy of "defending" and "legitimizing the work with public support". Undoubtedly, the protectiveness of scientific expertise is provided with provability. This puts researchers in a position where they have to face more destructive criticism compared to the past. Furthermore, society affirms the validity of studies to the extent that they prove to be beneficial. Otherwise, persuasiveness disappears. The issue of food security and social resilience is one that can be associated with these views. In practice, it is necessary to foresee that these views, which are benefit-oriented, can also bear features that are open to criticism under today's circumstances.

As you can see, food safety is primarily a national problem. It covers many disciplines and requires an interdisciplinary interest. In addition, communities 
with different religious and cultural structures that come with migration, whether they are homogeneous in certain regions or heterogeneous in the same area require a multifaceted assessment in terms of the integrity of the social structure at the local and national levels. In fact, the basic philosophy of public administration is to ensure social peace for sustainable management. Therefore, the keywords that local Agenda 21 meetings have communalized globally, such as "partnership in the solution", "active participation", and "city ownership" should always be taken into account. Countries can undoubtedly offer assistance to each other on different issues, as well as on food. However, this assistance should not be detrimental to the country's agricultural sovereignty (which is also valid for other sectors). It should be noted that the existence of agricultural or food insecurity has the capacity to open the doors to poverty and all aspects of terrorism, and human-induced threats can spread from country to country like a new virus.

\section{Evaluation and Conclusion}

The issue of "Health and Food Safety and Sufficiency" needs to be handled with a perspective that uses and develops and in which public administration needs to act in line with the national interest. New areas are being opened up for agricultural activities. And agricultural areas are losing their functionality due to climate change, managerial difficulties, and most importantly, the fact that people are not facing the challenges of the countryside and feeling distant from agriculture. In relation to this situation, it is required to strengthen agriculture, to regulate legal sanctions, to make use of public universities and integrated sectoral power for information support, and to support them for these purposes. Privatization should have some limits to support public services. In the global neighborhood, where disasters are increasing and diversifying, unfortunately, countries are keeping what is theirs and not being "generous" in terms of humanitarian aid to other countries. So, being self-sufficient and productive in the agricultural sector has become a general rule for Turkey as well as for every country. The general public thinks of this phenomenon with a utilitarian aspect, in which the threats of the virus are transformed into opportunities for Turkey.

To what extent does the pandemic provide food security and food dominance in national production in other countries is an important issue that needs to be examined in the upcoming years. This issue is related to the ecological dimension of imperialism. It is the main indicator of deprivation associated with external dependence.

A global problem is a reminder of why ethical cooperation on a global scale is necessary. In this case, it is necessary to have more faith in international organizations. However, having faith will only become common once the global cooperation is more prominent. Therefore, there must be access to shared information. In addition, equal responsibilities should be included in the partnership. For example, in the case of external migration, we cannot say that we have re- 
ceived the necessary and sufficient support for illegal irregular external migration from the "Council of Europe" which we have been a member of since the 1950 s and from the member states of the "European Union" with which we co-operate. In fact, it is necessary to realize that there is a need for a political environment where universal regulations are prepared for the negative circumstances brought by today's realities not just on commercial terms, but also from a human rights perspective.

The health systems in days of a global outbreak are actually "non-sum" whether the countries are developed or not. However, weaknesses in health systems can negatively affect some groups in developed countries as well. In underdeveloped countries, as in other types of disasters, unemployment and poverty-related negative effects are more common. As in developed countries, the success of returning to its former state is unpredictable. As you know, especially in global events, global internet access quickly makes the weak and the powerful separate from each other. But it is now known that "we are as strong as the weakest link". In addition, in terms of the accepted code of ethics, failure can also lead to loss of managerial reputation.

There is a tendency to define an action as "terrorism" and the perpetrator "terrorist" only when that action is considered illegitimate, contrary to universal law, and inconsistent. Can acts intended to prevent the widespread use of mechanisms that prevent events that threaten security be evaluated in the context of crimes against the state and defined as terrorism? This is an important question. For example, the behavior of people who cause the spread of the COVID-19 virus and who do not care to be protective on an individual basis has been associated with the crime and has been fined. In fact, in Italy, even imprisonment has been on the agenda. However, people insist on not obeying the administrative measures taken to protect society and for safety purposes. "Being fined" is not seen as a cause for embarrassment. What kind of methodology will be used in this case? Considering that terrorist tactics have changed according to the human factor and the actual event, every behavior that threatens security has a characteristic that can be associated with "intimidation" and "being intimidating" on which the word terror is based. For example, attacks towards law enforcement officials, such as soldiers or police, and civilians in public places are considered to be part of terrorism. Should people who attack or even spit on official security officers or officials who invite them to comply with the administration's rules be considered terrorists and their actions considered crimes against the state?

How safe environments and "smart society" relations should be regulated is an issue that needs to be quickly and carefully regulated, in the "New World Order of Corona" where such Corona cases will continue to happen. Although this statement varies from country to country, despite informing them, when a person is left free, they create an environment without vigilance where there is no safety left. It seems that the administration needs to work more scientifically 
on persuasion in disasters. In other words, managing disasters requires "organizational wisdom".

In order for people not to feel depressed as the periods they stay home will elongate, they need to acknowledge the fact that the key to success in terms of being in high spirit is self-development in line with personal working capacity, keeping busy, working until one feels tired and starting over when everything is finished. Information smart society and access to life quality indicators are not things that should be left away from society's opinion. It is the necessity of our age to monitor and supervise the people who take on the executive roles carefully and wisely and to carefully and intelligently elect them for these duties.

The fact that interdisciplinary and interdisciplinary studies will create the potential to accelerate the achievement of the stated goals makes it necessary for states to allocate budgets and place importance on these studies. Apparently, the Coronavirus pandemic will be with us forever, scientist warns.

\section{Conflicts of Interest}

The author declares no conflicts of interest regarding the publication of this paper.

\section{References}

BBC News (2017). Buzullarda saklı hastalıklar yeniden canlanıyor. https://www.bbc.com/turkce/vert-earth-39874249

Capital's Initiative for COVID-19 (2020). Portal. https://www.capitalsinitiative.org

Council of Europe (1992). European Urban Charter. https://rm.coe.int/168071923d

Council of Europe (2020a). Convention for the Protection of Human Rights and Fundamental Freedoms (ETS No. 5). https://www.coe.int/en/web/conventions/full-list/-/conventions/webContent/62111354

Council of Europe (2020b). COVID-19: Co-Operation and External Relations. https://www.coe.int/en/web/congress/COVID-19-co-operation-and-external-relations

Euronews (2019). Türkiye’de tarım alanları azalıyor, çiftçi sayısı yüzde 38 düştü. https://tr.euronews.com/2019/02/20/turkiye-de-ciftci-sayisi-yuzde-38-dustu-tarim-alan i-yuzde-12-azaldi

FAO (2020). Portal. http://www.fao.org/FOCUS/E/rightfood/right2.htm

Haber, T. (2015). 600 bin çiftçi üretimden çekildi! https://www.tarimdanhaber.com/tarimsal-ekonomi/600-bin-ciftci-uretimden-cekildi-h 2197.html

Hendriks, S. L., \& Maunder, E. (2006). Identification of Food Safety Indicators for FIVIMS. ZA. Unpublished Paper Prepared for the World Food Programme. Pietermaritzburg: University of KwaZulu-Natal.

Hulme, M. (2016). Íklim Değişikliği Konusunda Neden Anlaşamıyoruz? Why Can't We Agree on Climate Change (Translated by Merve Özenc). Istanbul: Alfa Yayınları.

International Federation of Red Cross and Red Crescent Societies (2018). World Disasters Report 2018. https://media.ifrc.org/ifrc/world-disaster-report-2018

Izmir Directorate of Provincial Agriculture and Forestry (2020). Portal. https://izmir.tarimorman.gov.tr 
Legendre, M. et al. (2015). In-Depth Study of Mollivirus sibericum, a New 30,000-Y-Old Giant Virus Infecting Acanthamoeba. PNAS, 112, E5327-E5335.

https://www.pnas.org/content/pnas/early/2015/09/02/1510795112.full.pdf https://doi.org/10.1073/pnas.1510795112

Public Health General Directorate (2020). T.C. Sağlık Bakanlı̆ğ Covid-19 Bilgilendirme Sayfası (Republic of Turkey the Ministry of Health Covid-19 Information Page). https://covid19.saglik.gov.tr/

Toprak, Z. (1990). Tourism Activities in Coastal Settlements and Problems Faced by Municipalities-Example of Cesme Municipality Example. Amme Ídaresi Dergisi, 24, 111-129.

Toprak, Z. (2014). Yerel Yönetimler (Local Administrations) (9th ed.). Izmir: Siyasal Kitabevi.

Toprak, Z. (2019a). Effects of Climate Change-Related Natural Disasters on Agricultural Activities, Social Awareness Analysis. In A. Mengi, \& D. İşçioğlu (Eds.), Rural Development and Cooperative System (pp. 299-325). Ankara: Publishing of Ankara University.

Toprak, Z. (2019b). Coastal Law and Coastal-Border Security in Terms of Disaster Administration. In Z. T. Karaman, \& O. Sancakdar (Eds.), Disasters and Safety Administration (pp. 219-243). Ankara: Palme Yayınevi.

Turkish Healthy Cities Association (Date Not Specified). About the Union. http://www.skb.gov.tr/birlik-hakkinda/birlik-hakkinda

UN (2009). Human Security in Theory and Practice. https://www.undp.org/content/dam/turkey/docs/news-from-new-horizons/issue-41/U NDP-TR-HSHandbook_2009.pdf

United Nations (1994). Human Development Report 1994. http://hdr.undp.org/sites/default/files/reports/255/hdr_1994_en_complete_nostats.pdf

United Nations General Assembly (1992). A/Conf.151/26 (Vol. I) Report of the United Nations Conference On Environment and Development. https://www.un.org/en/development/desa/population/migration/generalassembly/docs /globalcompact/A_CONF.151_26_Vol.I_Declaration.pdf

WHO (2020). Portal. https://www.who.int 